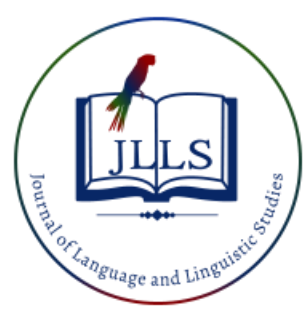

Available online at www.jlls.org

\section{JOURNAL OF LANGUAGE} AND LINGUISTIC STUDIES

ISSN: $1305-578 \mathrm{X}$

Journal of Language and Linguistic Studies, 16(4), 1921-1938; 2020

\title{
The awareness of ELL students about their 21st century skills
}

\author{
Aydan Irgatoğlu a 1 iD, Gülsev Pakkan b iD \\ a Ankara Hacı Bayram Veli University, Ankara, Turkey \\ ${ }^{b}$ Selçuk University, Konya, Turkey
}

Irgatoğlu, A. \& Pakkan, G. (2020). The awareness of ELL students about their 21st century skills? Journal of Language and Linguistic Studies, 16(4), 1921-1938.

Submission Date:17/08/2020

Acceptance Date:09/12/2020

\begin{abstract}
This study investigates the 21st century skills of the third and fourth year students studying at the Department of English Language and Literature of two Turkish state universities. Additionally, this study reveals the levels of the 21 st century skills of these students. To this end, a case study has been designed and conducted with 158 ELL students and 20 lecturers of the same department. The study has been conducted throughout the 2019-2020 academic year. In this study we review the related literature and we have chosen the two appropriate research instruments to collect the data. These instruments include a survey questionnaire for the students and a survey questionnaire for the lecturers are used to investigate the 21 st century skills of ELL students. The quantitative analysis of the data reveals that the students in these ELL departments are aware of their own 21st century skills. Another conclusion of this study demonstrates that although most of the students stated that they already use most of the 21 century skills, the lecturers do not readily approve of them. The lecturers stated that the students did not use different thinking techniques to create original ideas in their lives, evaluate new ideas by using analysis, work patiently to produce solutions to the problems, and the students did not take steps to improve their skills. Additionally, the lecturers disagreed with the statements that the students listened to other's opinion about a subject, had effective communication skills, adapted to different roles in their lives, were open to criticism, knew that learning was a lifelong process, knew that media was effective in directing people's opinion, used appropriate media tools to get information and used technological tools to analyse information.
\end{abstract}

(C) 2020 JLLS and the Authors - Published by JLLS.

Keywords: $21^{\text {st }}$ century skills; ELL students; learning and innovation skills; life and career skills; information, media and technology skills

\section{Introduction}

The recent changes in the world such as globalisation, migration, international competition, changing markets, environmental and political changes, and the growing importance given to information and communication technology have introduced great challenges for the new millennium (Ahmed, 2018; Tican \& Deniz 2018; Sümen \& Çalışıc1, 2017). When we take these changes into consideration, it is so

\footnotetext{
${ }^{1}$ Corresponding author.

E-mail address: aydan.irgatoglu@hbv.edu.tr
} 
obvious that the competences and skills in the 21st century in terms of professional life, citizenship, and self-actualization will be highly different from the competences and skills needed in the 20th century (Tican \& Deniz, 2018). For example, we have been experiencing the use of computers in every context in our lives for a long time and even a new generation has emerged. This new generation have been born into the digital technology age and have been growing up with the effects of the technological developments. Therefore, the young generation need to be equipped with some new competencies and skills. These skills are called the ' 21 st Century Skills'. We can define these 21 st century skills as the combination of the knowledge, skill, literacy, and expertise that are necessary for individuals to be successful in work and daily life ("Partnership for 21st Century Skills", 2009). Therefore, it is so important to prepare young people for the 21st century so that they can adapt themselves to the professional life, social values, and life as a whole in the coming century.

The countries in the world have been reshaping their education systems in the framework of the above-mentioned urgency of developing the set of competences and skills that are needed in order to survive and be effective in the 21 st century. Needless to say, the same challenge applies for the education system in Turkey at all levels. Several adaptations have been done at the primary and secondary schools. The Ministry of National Education has renewed the curricula and has incorporated some of these 21st century skills. There are also some attempts to reform the curricula implemented at the tertiary level, i.e. at our universities. Especially, some research has been carried out to help the faculties of education to renew their curricula in terms of teacher education. However, we believe that, such studies have not been done to reshape the teaching of literature courses at the departments of English Language and Literature in our country. Literature is generally taught in a traditional way with the assumption or presupposition that that transmitting a set of authors and their works will be enough (Ahmed, 2018). However, some scholars believe that instruction of literature requires skills and competences necessary to read and understand literary texts effectively. Moreover, instruction of literature can enhance the literary experience of students, i.e. the discovery of the aesthetic value of the literary texts, appreciating their literary merit, their significance within the social history (Ahmed, 2018).

It must be emphasized that literature can be considered as a very useful source for language teaching and learning process. In particular, literary texts can be very good instruments to develop the reading, listening, writing, and speaking skills of the students attending the language and literature departments. In other words, literature contains a variety of linguistic components that provides learners a variety of opportunities to increase their language awareness in four basic language skills.

The teaching of literature is also a very significant tool to integrate the cultural elements to the linguistic awareness of the students. Thus, the students can become aware of the cultural differences, have a variety of perspectives, and be more tolerant toward other cultures in the world.

Thus, it is believed that the 21st century skills can help the learners studying at the Department of English Language and Literature in Turkish state universities be competent in the above-mentioned skills. Therefore, we need to carry out some research about the 21 st century skills of these students and make the necessary changes in the curricula accordingly.

\subsection{Literature review}

In this part, first, the 21st century skills will be defined according to some scholars/ organizations. Then, the studies carried out to find out the 21st century skills of some learners within the context of the primary, secondary, and tertiary levels in the education systems of some countries in the world as well as in Turkey. 


\section{What are the 21 st century skills?}

The rapid changes and developments in the world have made it essential for learners to equip themselves with new competencies and skills. As well as the basic competencies and skills acquired, it is necessary for learners to possess higher level skills and competencies that will help them catch up with the changes in the world, to catch up with technological development, to acquire new knowledge, analysing and evaluating information, to use the acquired knowledge in everyday life and convert it into product (Kan \& Murat, 2018). All of these skills are called the 21st century skills today. They are the combination of the knowledge, skill, literacy, and expertise which are specifically necessary for individuals to be successful in work and in daily life ("Partnership for 21st Century Skills", 2009). Actually, in the literature reviewed, there is no universal definition of the 21 st century skills (Tican \& Deniz, 2019). There are different categorizations/ classifications of these skills. For example, according to Trilling and Fadel (2009) and Partnership 21 (2015), the 21st century skills are grouped under three headings which are Life and Career skills, Learning and Innovation skills, and Information Technologies Skills.

The 21st century skills are categorized under three headings, by The National Research Council, which are cognitive skills, interpersonal skills and management process. (Sümen \& Çalışıcı, 2017). Moreover, seven survival skills that are necessary for learners to specialize in to succeed in business life are described by Wagner (2008). Wagner identifies these survival skills as a result of some interviews with a lot of leaders in the job market. These skills are: critical thinking and problem-solving, collaboration and leadership, agility and adaptability, initiative and entrepreneurialism, effective oral and written communication, accessing and analysing information, and curiosity and imagination (Tican \& Deniz, 2019).

In a project conducted by OECD, Pedro (2006) identifies the characteristic skills of learners as "alternative cognitive skills", "changes in cultural practices and social values" and "expectations for teaching and learning".

\section{1 st century skills in the education studies}

Recently, the 21st century skills have increasingly given a way to various changes in the education systems of many countries in the world. Therefore, extensive research has been carried out to understand the 21 st century skills of these education systems. These research studies have been carried out the at the primary, secondary, and tertiary levels of education. For example, to measure the 21 st century skills of primary school students, a scale was developed by Kang, Kim, Kim, and You (2012). All those skills were categorized under three fields which were "cognitive field (information management, information construction, information use, and problem-solving), affective field (self-identity, self-value, selfmanagement, and self-responsibility), and sociocultural field (social membership, social sensitiveness, socialization skills, and social accomplishments)" (Sümen \& Çalışıcı, 2017).

To be able to equip primary school students with $21^{\text {st }}$ century skills and knowledge, Cho (2012) examined the teaching methods used. Then, he found out four main themes that were "cultural support for implementation and cooperation, effective leadership for realizing the school's vision and goals, the strong nexus between the school's vision and goals and the program and its applications, and the integration of technology into the classroom". After the analysis of the results, he emphasized the importance of technology in primary education program and claimed that Project-based learning activities help students work cooperatively by improving the students' communication, problemsolving, and creativity skills (Sümen \& Çalışıcı, 2017).

Within this framework, some other studies have been carried out, such as the identification of the school, classroom, and student factors that are necessary for the development of the 21 st century skills, 
how the 21 st century skills are integrated into the lessons, the development of a new literacy model which includes the 21st century skills, and the development of a scale (Sümen \& Çalışıc1, 2017).

There are also studies carried out to identify the 21 st century skills of the secondary school students. For example, Sümen and Çalışıcı (2017) investigated the 21st century skills of the fifth grade students in a secondary school in Turkey during the 2015-16 academic year. Mixed method research design including both qualitative and quantitative data was used in the study. The analysis of data revealed that most of the students were using the $21^{\text {st }}$ century skills actively and the skills of female students are more highly developed than those of male students. Additionally, it was found out that the 21 st century skill levels of 5th grade students were better than those of students in other classes.

There are also studies at the tertiary level, especially in the education of pre-service teachers. Günüç, Odabaşı, and Kuzu (2013) determined how student teachers identified the characteristics of the 21st century students and categorized the characteristics under four themes as personal skills, investigative and knowledge acquisition skills, creative, innovative, and career skills and technological skills with some subthemes.

In a study carried out by Tican and Deniz (2018), the purpose was to determine the pre-service teachers' opinions about the 21st century learner and teacher skills. The 21 st century Learner Skills Use Questionnaire and 21st Century Teacher Skills Use Questionnaire were used to collect data. When the results were analysed, it was found out that, the pre-service teachers were ready to use those skills and their opinions about the 21 st century learner and teacher skills varied significantly depending on the variables of gender, department attended, academic achievement, experience of private tutoring and practicum teaching. However, the pre-service teachers had some difficulties in using the learner and teacher skills during their practicum teaching.

In another study, Bedir (2019) investigated the ELT pre-service teachers' beliefs and perceptions about the 21 st century learning and innovation skills with a special emphasis on critical, creative thinking, collaboration and communication skills (4Cs) in particular. A questionnaire and semistructured interviews were used to collect data. According to the results, pre-service teachers were aware of and involved in 4Cs though they had high positive perceptions towards them. On the other hand, they held negative beliefs about the emphasis of the 4Cs in the national curriculum and assessment, but positive beliefs about professional development for 4 Cs.

\subsection{Research questions}

It is hypothesized in this study that a research has not been carried out to identify the 21 st century skills of the third and fourth year students at the department of English Language and Literature of two Turkish state universities. However, it is believed that these students need these 21st century skills so that they can be successful in the literature courses at their departments. As a short-term goal, these students need to possess the 21 st century skills to understand and interpret the literary texts successfully in the framework of creativity, leadership, reflective thinking, problem solving, and collaboration that are the basic 21st century skills. But, as a long-term goal, we expect them to graduate equipped with these skills that will help them to understand the 21 st century literature and survive successfully in everyday life and work. In order to achieve these goals, we believe that a new understanding of literature teaching has to be established in the light of the findings about the students' 21 st century skills. In the light of these hypotheses, the research questions of the present study are:

1) Are the students of ELL departments of two Turkish state universities aware of their own 21st century skills?

2) What are the levels of the 21st century skills of the students of the ELL Departments of two Turkish state universities? 
As can be understood from the research questions presented in I.1, the basic aim of this study is to find out whether the students studying English Language and Literature at two Turkish state universities are aware of their own 21 st century skills. The second aim of this research is to identify the 21 st century skills of these students.

\section{Method}

This study was based on descriptive research method and survey research method. Descriptive research is done to clarify a situation and/or describe the characteristics of a specific population or phenomenon that is being studied. Descriptive research is used to obtain information about the current status of the phenomenon to describe 'what exists' with respect to conditions in a situation. There are three types of descriptive research: observational method, case-study method and survey method. In survey method, respondents answer through surveys or questionnaires, or polls.

\subsection{Participants}

The participants of the current research are 158 third and fourth year students of the Department of English Language and Literature of two state universities in Turkey and 20 lecturers working at those departments. The students have been selected through convenience sampling which is one of the purposive sampling methods. A total of 158 students have participated in the study on a volunteer basis.

The distribution of the student participants according to the variables is shown in Table 1.

Table 1. General characteristics of the student participants

\begin{tabular}{llllll}
\hline \multicolumn{5}{c}{ Gender } & \multicolumn{3}{l}{ Age } \\
\hline Frequency & Female & Male & $18-20$ & $20-22$ & $23+$ \\
\hline Percentage & 100 & 58 & 16 & 98 & 44 \\
\hline
\end{tabular}

When Table 1 is considered, it can be observed that females constitute $63.29 \%$ of the participants, while males form $36.7 \%$ of the students studying at the English Language and Literature Departments of two Turkish state universities. Additionally, 16 of the participants (p.10.12\%) were aged between 1820,98 of them (p.62\%) were aged between 20-22, and 44 of them (p.27.8\%) were 23 or older.

The distribution of the lecturer participants is shown in Table2.

Table 2. General characteristics of the lecturer participants

\begin{tabular}{llllll}
\hline & \multicolumn{4}{c}{ Gender } & \multicolumn{4}{c}{ Academic Title } \\
\hline Frequency & Female & Male & Professor & Assoc Prof & Asst.Prof \\
\hline Percentage & 15 & 5 & 3 & 1 & 16 \\
\hline
\end{tabular}

As Table 2 suggests, most of the lecturers (p.75\%) were females. In terms of academic title, 3 professors, 1 associate professor and 16 assistant professors participated in the study. 


\subsection{Instrument(s)}

In order to collect data for the present study, "21st Century Skills Competencies Perception Scale" developed by Anagün, Atalay, Kılıç and Yaşar (2016) has been used to determine the 21st century skills of the students studying English Language and Literature at two Turkish state universities. This questionnaire has used the theoretical framework presented in Trilling and Fadel (2009) and Partnership 21 (p.21, 2015). Additionally, this scale has been adapted for lecturers to share their opinions about the use of 21 st century skills of ELL students. Both scales consist of 42 items in total. These items are categorized under 3 groups of skills: "Learning and Innovation Skills", "Life and Career Skills", and "Information, Media and Technology Skills". The evaluation for each item has been done in a scale from Strongly Disagree, Agree, Undecided, Agree, to Strongly Agree.

The reliability of this study was measured through the SPSS Statistic 22 Programme. The Cronbach Alfa scores of the questionnaire are shown in Table 3.

Table 3. Cronbach Alfa Coefficients of the scale

\begin{tabular}{ll}
\hline Items & Cronbach Alfa Coefficients \\
\hline Learning and Innovation Skills & 0.90 \\
\hline Life and Career Skills & 0.91 \\
\hline Information, Media and Technology Skills & 0,89 \\
\hline
\end{tabular}

When the Cronbach Alpha coefficients of the items were examined, it was clear that all the coefficients were above 0.80 . The reliability of the whole scale was measured as $90 \%(0.90)$. Due to the fact that $0.80 \leq \alpha<1.00$ scale is highly reliable, these findings show that the scale is highly reliable.

\subsection{Data analysis}

Likert type items used to collect data were analysed using quantitative research methods. The data obtained from Likert type items were processed in SPSS 22.0. Frequency and percentage techniques were used in calculations. Arithmetic mean was also used for the analysis of Likert type items to determine the attitude of ELL students towards the use of 21st century skills.

\section{Results}

The students studying at the English Language and Literature Departments of two Turkish state universities were asked to express their views regarding the use of 21 st century skills for learning. To measure their use of 21 st century skills for learning, a Likert Scale was used in the questionnaire. The statements in the questionnaire were interrelated. As a result, they were grouped into three categories, which were "learning and innovation skills, life and career skills, and information, media and technology skills."

\section{Learning and Innovation Skills}

Eighteen items in the questionnaire were related to learning and innovation skills used by the ELL students. Table 4 presents some information given by the students about the use of these 21 st century skills for learning. 
Table 4. Learning and innovation skills (students)

\begin{tabular}{|c|c|c|c|c|c|c|}
\hline & $\begin{array}{l}\text { Strongly } \\
\text { Disagree }\end{array}$ & Disagree & Undecided & Agree & $\begin{array}{l}\text { Strongly } \\
\text { Agree }\end{array}$ & $\overline{\mathrm{x}}($ Mean $)$ \\
\hline \multicolumn{6}{|c|}{ Item 1. "I develop original ideas for solving the problems I encounter". } & 3.70 \\
\hline Frequency & 4 & 10 & 38 & 82 & 24 & \\
\hline Percentage & 2.6 & 6.4 & 24 & 51.9 & 15.1 & \\
\hline \multicolumn{6}{|c|}{$\begin{array}{l}\text { Item 2. "I use different thinking techniques (brainstorming, six thinking hat) to create original } \\
\text { ideas in my life". }\end{array}$} & 3.63 \\
\hline Frequency & 6 & 28 & 16 & 76 & 32 & \\
\hline Percentage & 3.8 & 17.8 & 10.1 & 48.1 & 20.2 & \\
\hline \multicolumn{6}{|c|}{ Item 3. "I try different solutions to bring a problem to a conclusion". } & 3,84 \\
\hline Frequency & 4 & 8 & 10 & 122 & 14 & \\
\hline Percentage & 2.6 & 5.1 & 6.3 & 77.1 & 8.9 & \\
\hline \multicolumn{6}{|c|}{ Item 4. "I establish out of the ordinary relations between part and the whole" } & 3,48 \\
\hline Frequency & 4 & 12 & 62 & 64 & 16 & \\
\hline Percentage & 2.6 & 7.6 & 39.2 & 40.5 & 10.1 & \\
\hline \multicolumn{6}{|c|}{ Item 5. "I use imagination to solve problems". } & 4,08 \\
\hline Frequency & - & 14 & 14 & 74 & 56 & \\
\hline Percentage & - & 8.9 & 8.9 & 46.8 & 35.4 & \\
\hline \multicolumn{6}{|c|}{ Item 6. "I evaluate new ideas by using analysis" } & 3,97 \\
\hline Frequency & - & 6 & 28 & 88 & 36 & \\
\hline Percentage & & 3.8 & 17.7 & 55.7 & 22.8 & \\
\hline \multicolumn{6}{|c|}{ Item 7. "I try to understand the different dimensions of a topic". } & 4,05 \\
\hline Frequency & - & 6 & 16 & 100 & 36 & \\
\hline Percentage & & 3.8 & 10.1 & 63.3 & 22.8 & \\
\hline \multicolumn{6}{|c|}{ Item 8. "When solving the problem, I ask questions to determine the different points of view". } & 4,11 \\
\hline Frequency & 2 & 6 & 16 & 82 & 52 & \\
\hline Percentage & 1.3 & 3.8 & 10.1 & 51.9 & 32.9 & \\
\hline \multicolumn{6}{|c|}{ Item 9. "I work patiently to produce solutions to the problems." } & 3,30 \\
\hline Frequency & 2 & 48 & 30 & 56 & 22 & \\
\hline Percentage & 1.3 & 30.3 & 19 & 35.4 & 13.9 & \\
\hline \multicolumn{6}{|c|}{ Item 10. "I search for the basis of a view by questioning the claim." } & 3,67 \\
\hline Frequency & 6 & 6 & 34 & 100 & 12 & \\
\hline Percentage & 3.8 & 3.8 & 21.5 & 63.2 & 7.6 & \\
\hline \multicolumn{6}{|c|}{ Item 11. "I use reasoning methods to solve problems." } & 3,84 \\
\hline Frequency & 2 & 8 & 26 & 98 & 24 & \\
\hline Percentage & 1.3 & 5.1 & 16.4 & 62 & 15.1 & \\
\hline \multicolumn{6}{|c|}{ Item 12. "In problem solution, I analyse the relation between the part and the whole." } & 3,86 \\
\hline Frequency & 4 & 8 & 30 & 80 & 36 & \\
\hline Percentage & 2.6 & 5.1 & 19 & 50.6 & 22.7 & \\
\hline \multicolumn{6}{|c|}{ Item 13. "I consider different points of view." } & 4,25 \\
\hline Frequency & 2 & 4 & 8 & 82 & 62 & \\
\hline Percentage & 1.3 & 2.6 & 5.1 & 51.9 & 39.2 & \\
\hline \multicolumn{6}{|c|}{ Item 14. "I create synthesis by establishing relations between information and arguments" } & 3,51 \\
\hline Frequency & 6 & 20 & 38 & 74 & 20 & \\
\hline Percentage & 3.8 & 12.6 & 24 & 46.8 & 12.6 & \\
\hline \multicolumn{6}{|c|}{ Item 15. "I research conclusions by analysing information" } & 3,79 \\
\hline Frequency & 2 & 16 & 20 & 94 & 26 & \\
\hline Percentage & 1.3 & 10.1 & 12.6 & 59.4 & 16.4 & \\
\hline \multicolumn{6}{|c|}{ Item 16. "I share the knowledge I acquire with others in different ways (written, oral, etc.)" } & 4,16 \\
\hline Frequency & - & 2 & 20 & 86 & 50 & \\
\hline
\end{tabular}




\begin{tabular}{|c|c|c|c|c|c|c|}
\hline Percentage & & 1.3 & 12.6 & 54.4 & 31.6 & \\
\hline \multicolumn{6}{|c|}{ Item 17. "I use time effectively" } & 2,60 \\
\hline Frequency & 22 & 62 & 38 & 28 & 8 & \\
\hline Percentage & 13.9 & 39.2 & 24 & 17.7 & 5.1 & \\
\hline \multicolumn{6}{|c|}{ Item 18. "I take steps to improve my skills" } & 3,87 \\
\hline Frequency & - & 14 & 26 & 84 & 34 & \\
\hline Percentage & & 8.87 & 16.4 & 53.1 & 21.5 & \\
\hline TOTAL & & & & & & 3,76 \\
\hline
\end{tabular}

When the mean values given in Table 4 regarding the "learning and innovation skills" were considered, it could be claimed that the items with the highest level of agreement were "I consider different points of view" $(\overline{\mathrm{x}}=4,25)$, "I share the knowledge I acquire with others in different ways (written, oral, etc.)" $(\overline{\mathrm{x}}=4,16)$, "When solving the problem, I ask questions to determine the different points of view" $(\overline{\mathrm{x}}=4,11)$, "I use imagination to solve problems" $(\overline{\mathrm{x}}=4,08)$, and "I try to understand the different dimensions of a topic" ( $\overline{\mathrm{x}}=4,05)$. On the other hand, the lowest level of agreement was observed for items "I use time effectively" ( $\overline{\mathrm{x}}=2,60)$, "I work patiently to produce solutions to the problems" ( $\overline{\mathrm{x}}=3,30)$, and "I establish out of the ordinary relations between part and the whole" $(\overline{\mathrm{x}}=$ $3,48)$.

According to the research findings, participant ELL students studying at state universities responded "agree" to most of the eighteen items in the 21 st century skills competence perceptions "learning and innovation skills" dimension $(\overline{\mathrm{x}}=3,76)$. However, learning and innovation skills were not used by the students as much as the other $21^{\text {st }}$ century skills.

This scale was adapted for lecturers to share their opinions about the use of the 21 st century skills of ELL students. Table 5 presents some information about the opinions of the lecturers in terms of learning and innovation skills used by the ELL students

Table 5. Learning and innovation skills used by ELL students

\begin{tabular}{|c|c|c|c|c|c|c|}
\hline & $\begin{array}{l}\text { Strongly } \\
\text { Disagree }\end{array}$ & Disagree & Undecided & Agree & $\begin{array}{l}\text { Strongly } \\
\text { Agree }\end{array}$ & $\overline{\mathrm{x}}($ Mean $)$ \\
\hline \multicolumn{7}{|c|}{ Item 1. "My students develop original ideas for solving the problems they encounter". } \\
\hline Frequency & - & - & - & 19 & 1 & 4,05 \\
\hline Percentage & & & & 95 & 5 & \\
\hline \multicolumn{7}{|c|}{ to create original ideas in their lives" } \\
\hline Frequency & - & 18 & 1 & 1 & - & \\
\hline Percentage & - & 90 & 5 & 5 & - & \\
\hline \multicolumn{6}{|c|}{ Item 3. "My students try different solutions to bring a problem to a conclusion." } & 4,05 \\
\hline Frequency & - & - & - & 19 & 1 & \\
\hline Percentage & - & - & - & 95 & 5 & \\
\hline \multicolumn{6}{|c|}{ Item 4. "My students establish out of the ordinary relations between part and the whole" } & 3 \\
\hline Frequency & - & - & 20 & - & - & \\
\hline Percentage & - & - & 100 & - & - & \\
\hline \multicolumn{6}{|c|}{ Item 5. "My students use imagination to solve problems". } & 4,05 \\
\hline Frequency & - & - & - & 19 & 1 & \\
\hline Percentage & - & - & - & 95 & 5 & \\
\hline \multicolumn{6}{|c|}{ Item 6. "My students evaluate new ideas by using analysis" } & 2,1 \\
\hline Frequency & - & 18 & 2 & - & - & \\
\hline Percentage & & 90 & 10 & - & - & \\
\hline
\end{tabular}




\begin{tabular}{|c|c|c|c|c|c|c|}
\hline \multicolumn{6}{|c|}{ Item 7. "My students try to understand the different dimensions of a topic". } & \multirow[t]{2}{*}{3,9} \\
\hline Frequency & - & - & 2 & 18 & - & \\
\hline Percentage & & - & 10 & 90 & - & \\
\hline \multicolumn{6}{|c|}{$\begin{array}{l}\text { Item } 8 \text {. "When solving the problem, my students ask questions to determine the different } \\
\text { points of view". }\end{array}$} & 4 \\
\hline Frequency & - & - & - & 20 & - & \\
\hline Percentage & - & - & - & 100 & - & \\
\hline \multicolumn{6}{|c|}{ Item 9. "My students work patiently to produce solutions to the problems". } & 2,15 \\
\hline Frequency & - & 18 & 1 & 1 & - & \\
\hline Percentage & - & 90 & 5 & 5 & - & \\
\hline \multicolumn{6}{|c|}{ Item 10. "My students search for the basis of a view by questioning the claim". } & 3,05 \\
\hline Frequency & - & - & 19 & 1 & - & \\
\hline Percentage & - & - & 95 & 5 & - & \\
\hline \multicolumn{6}{|c|}{ Item 11. "My students use reasoning methods to solve problems". } & 4,15 \\
\hline Frequency & - & - & - & 17 & 3 & \\
\hline Percentage & - & - & - & 85 & 15 & \\
\hline \multicolumn{6}{|c|}{$\begin{array}{l}\text { Item 12. "In problem solution, my students analyse the relation between the part and the } \\
\text { whole". }\end{array}$} & 3,8 \\
\hline Frequency & - & - & 4 & 16 & - & \\
\hline Percentage & - & - & 20 & 80 & - & \\
\hline \multicolumn{6}{|c|}{ Item 13. "My students consider different points of view". } & 4,1 \\
\hline Frequency & - & - & - & 18 & 2 & \\
\hline Percentage & - & - & - & 90 & 10 & \\
\hline \multicolumn{6}{|c|}{$\begin{array}{l}\text { Item 14. "My students create synthesis by establishing relations between information and } \\
\text { arguments" }\end{array}$} & 3,95 \\
\hline Frequency & - & - & 3 & 15 & 2 & \\
\hline Percentage & - & - & 15 & 75 & 10 & \\
\hline \multicolumn{6}{|c|}{ Item 15. "My students research conclusions by analysing information" } & 3,85 \\
\hline Frequency & - & - & 3 & 17 & - & \\
\hline Percentage & - & - & 15 & 85 & - & \\
\hline \multicolumn{6}{|c|}{$\begin{array}{l}\text { Item 16. "My students share the knowledge they acquire with others in different ways } \\
\text { (written, oral, etc.)" }\end{array}$} & 4 \\
\hline Frequency & - & - & - & 20 & - & \\
\hline Percentage & & - & - & 100 & - & \\
\hline \multicolumn{6}{|c|}{ Item 17. "My students use time effectively" } & 2 \\
\hline Frequency & - & 20 & - & - & - & \\
\hline Percentage & - & 100 & - & - & - & \\
\hline \multicolumn{6}{|c|}{ Item 18. "My students take steps to improve their skills." } & 3 \\
\hline Frequency & - & - & 18 & 2 & - & \\
\hline Percentage & & - & 90 & 10 & - & \\
\hline TOTAL & & & & & & 3,24 \\
\hline
\end{tabular}

According to the mean values given in Table 5 regarding the opinions of the lecturers in terms of learning and innovation skills used by the ELL students, it could be claimed that the items with the highest level of agreement were "My students use reasoning methods to solve problems" $(\overline{\mathrm{x}}=4,15)$, "My students consider different points of view" $(\overline{\mathrm{x}}=4,1)$, "My students develop original ideas for solving the problems they encounter" ( $\overline{\mathrm{x}}=4,05)$, "My students use imagination to solve problems" $(\overline{\mathrm{x}}=4,05)$, and "My students try different solutions to bring a problem to a conclusion" $(\overline{\mathrm{x}}=4,05)$. Diversely, the lowest level of agreement was observed for items "My students use time effectively" ( $\overline{\mathrm{x}}=2)$, "My students evaluate new ideas by using analysis" $(\overline{\mathrm{x}}=2,1)$, "My students work patiently to produce solutions to the 
problems" $(\overline{\mathrm{x}}=2,15)$ and "My students use different thinking techniques (brainstorming, six thinking hat) to create original ideas in their lives" $(\overline{\mathrm{x}}=2,15)$.

According to the research findings, although participant ELL students studying at state universities responded "agree" to most of the eighteen items in the 21 st century skills competence perceptions "learning and innovation skills" dimension $(\overline{\mathrm{x}}=3,76)$, the lecturers were mostly "undecided" about the use of those skills by their students $(\overline{\mathrm{x}}=3,24)$.

\section{Life and Career Skills}

Sixteen items in the questionnaire were related to life and career skills. Table 6 presents some information given by the students about the use of these 21st century skills for learning.

Table 6. Life and career skills

\begin{tabular}{|c|c|c|c|c|c|c|}
\hline & $\begin{array}{l}\text { Strongly } \\
\text { Disagree }\end{array}$ & Disagree & Undecided & Agree & $\begin{array}{l}\text { Strongly } \\
\text { Agree }\end{array}$ & $\begin{array}{c}\overline{\mathrm{x}} \\
(\text { Mean) }\end{array}$ \\
\hline \multicolumn{6}{|c|}{ Item 19. "I listen to other's opinion about a subject" } & 4,20 \\
\hline Frequency & 6 & 2 & 8 & 80 & 62 & \\
\hline Percentage & 3.8 & 1.3 & 5.1 & 50.6 & 39.2 & \\
\hline \multicolumn{6}{|c|}{ Item 20. "I have effective communication skills." } & 4,01 \\
\hline Frequency & 12 & 18 & 42 & 56 & 30 & \\
\hline Percentage & 7.6 & 11.4 & 26.5 & 35.4 & 19 & \\
\hline \multicolumn{6}{|c|}{ Item 21. "I have the ability to work effectively in group work" } & 3,75 \\
\hline Frequency & 2 & 24 & 28 & 70 & 36 & \\
\hline Percentage & 1.3 & 15.1 & 17.7 & 44.3 & 22.7 & \\
\hline \multicolumn{6}{|c|}{ Item 22. "I work in harmony with group members". } & 3,70 \\
\hline Frequency & 4 & 16 & 26 & 78 & 32 & \\
\hline Percentage & 2.6 & 10.1 & 16.4 & 49.3 & 20.2 & \\
\hline \multicolumn{6}{|c|}{ Item 23. "I take responsibility in group work." } & 4,20 \\
\hline Frequency & 2 & 8 & 6 & 82 & 60 & \\
\hline Percentage & 1.3 & 5.1 & 3.8 & 51.9 & 37.9 & \\
\hline \multicolumn{6}{|c|}{ Item 24. "I value individual contributions in group work" } & 4,10 \\
\hline Frequency & 4 & 4 & 14 & 86 & 50 & \\
\hline Percentage & 2.6 & 2.6 & 8.9 & 54.4 & 31.6 & \\
\hline \multicolumn{6}{|c|}{ Item 25. "I am flexible in changing my ideas based on others' suggestions." } & 3,63 \\
\hline Frequency & 6 & 14 & 34 & 82 & 22 & \\
\hline Percentage & 3.8 & 8.9 & 21.5 & 51.8 & 13.9 & \\
\hline \multicolumn{6}{|c|}{ Item 26. "I adapt to different roles (friends, citizens, economic, power, family members) in my life". } & 4,24 \\
\hline Frequency & - & 4 & 16 & 76 & 62 & \\
\hline Percentage & & 2.6 & 10.1 & 48.1 & 39.2 & \\
\hline \multicolumn{6}{|c|}{ Item 27. "I am not comfortable with adapting to new situations." } & 2,74 \\
\hline Frequency & 24 & 56 & 24 & 44 & 10 & \\
\hline Percentage & 15.1 & 35.4 & 15.1 & 27.8 & 6.3 & \\
\hline \multicolumn{6}{|c|}{ Item 28. "I am open to criticism." } & 3,98 \\
\hline Frequency & 4 & 8 & 18 & 84 & 44 & \\
\hline Percentage & 2.6 & 5.1 & 11.3 & 53.1 & 27.8 & \\
\hline \multicolumn{6}{|c|}{ Item 29. "I consider the different points of view to solve the problems". } & 4,10 \\
\hline Frequency & 2 & 6 & 10 & 96 & 44 & \\
\hline Percentage & 1.3 & 3.8 & 6.3 & 60.7 & 27.8 & \\
\hline \multicolumn{5}{|c|}{ Item 30. "I know that learning is a lifelong process." } & & 4,76 \\
\hline Frequency & - & - & 4 & 30 & 124 & \\
\hline
\end{tabular}




\begin{tabular}{|c|c|c|c|c|c|c|}
\hline Percentage & & & 2.6 & 18.9 & 78.4 & \\
\hline \multicolumn{6}{|c|}{ Item 31. "I make use of past experiences to predict future events." } & 4,38 \\
\hline Frequency & 2 & 4 & 6 & 66 & 80 & \\
\hline Percentage & 1.3 & 2.6 & 3.8 & 41.7 & 50.6 & \\
\hline \multicolumn{6}{|c|}{ Item 32. "I know when to talk and when to listen". } & 4,11 \\
\hline Frequency & 2 & 4 & 28 & 64 & 60 & \\
\hline Percentage & 1.3 & 2.6 & 17.7 & 40.5 & 37.9 & \\
\hline \multicolumn{6}{|c|}{ Item 33. "I am respectful in my communication with others." } & 4,12 \\
\hline Frequency & 6 & 8 & 14 & 62 & 68 & \\
\hline Percentage & 3.8 & 5.1 & 8.9 & 39.2 & 43 & \\
\hline \multicolumn{6}{|c|}{ Item 34."I respect to other cultures". } & 4,53 \\
\hline Frequency & 2 & 6 & 4 & 40 & 106 & \\
\hline Percentage & 1.3 & 3.8 & 2.6 & 25.3 & 67 & \\
\hline TOTAL & & & & & & 4,03 \\
\hline
\end{tabular}

Views of ELL students on "life and career skills" dimension of the 21 st century skills competencies scale were presented in Table 6. When the means related to this dimension were considered, the items with the highest level of agreement were "I know that learning is a lifelong process" $(\overline{\mathrm{x}}=4,76)$, "I respect to other cultures" ( $\overline{\mathrm{x}}=4,53)$, "I make use of past experiences to predict future events " $(\overline{\mathrm{x}}=4,38)$, and "I adapt to different roles (friends, citizens, economic, power, family members) in my life " $(\overline{\mathrm{x}}=$ 4,24). However, the lowest level of agreement was observed for items "I am not comfortable with adapting to new situations" $(\overline{\mathrm{x}}=2,74)$, "I am flexible in changing my ideas based on others' suggestions" $(\overline{\mathrm{x}}=3,63)$, and "I work in harmony with group members" $(\overline{\mathrm{x}}=3,70)$.

According to the research findings, participant ELL students responded "agree" to nearly all of the sixteen items in the 21st century skills competence perceptions "life and career skills" dimension $(\overline{\mathrm{x}}=$ 4,03). Although the ELL students were aware of life and career skills more than learning and innovation skills, those skills were not used by the students as much as information, media and technology skills.

This scale was also adapted for lecturers to share their opinions about the use of 21 st century skills of ELL students. Table 7 presents some information about the opinions of the lecturers in terms of life and career skills used by the ELL students

Table 7. Life and career skills used by ELL students

\begin{tabular}{|c|c|c|c|c|c|c|}
\hline & $\begin{array}{l}\text { Strongly } \\
\text { Disagree }\end{array}$ & Disagree & Undecided & Agree & $\begin{array}{l}\text { Strongly } \\
\text { Agree }\end{array}$ & $\overline{\mathrm{x}}($ Mean) \\
\hline \multicolumn{6}{|c|}{ Item 19. "My students listen to other's opinion about a subject." } & 2,20 \\
\hline Frequency & - & 18 & - & 2 & - & \\
\hline Percentage & - & 90 & - & 10 & - & \\
\hline \multicolumn{6}{|c|}{ Item 20. "My students have effective communication skills. " } & 2,10 \\
\hline Frequency & - & 18 & 2 & - & - & \\
\hline Percentage & - & 90 & 10 & - & - & \\
\hline \multicolumn{6}{|c|}{ Item 21. "My students have the ability to work effectively in group work". } & 4 \\
\hline Frequency & - & - & - & 20 & - & \\
\hline Percentage & - & - & - & 100 & - & \\
\hline \multicolumn{6}{|c|}{ Item 22."My students work in harmony with group members." } & 4 \\
\hline Frequency & - & - & - & 20 & - & \\
\hline Percentage & - & - & - & 100 & - & \\
\hline \multicolumn{6}{|c|}{ Item 23."My students take responsibility in group work." } & 3,6 \\
\hline Frequency & - & - & 8 & 12 & - & \\
\hline Percentage & - & - & 40 & 60 & - & \\
\hline
\end{tabular}




\begin{tabular}{|c|c|c|c|c|c|c|}
\hline \multicolumn{6}{|c|}{ Item 24."My students value individual contributions in group work". } & \multirow[t]{2}{*}{4,05} \\
\hline Frequency & - & - & - & 19 & 1 & \\
\hline Percentage & - & - & - & 95 & 5 & \\
\hline \multicolumn{6}{|c|}{ Item 25. "My students are flexible in changing their ideas based on others' suggestions." } & 3,6 \\
\hline Frequency & - & - & 8 & 12 & - & \\
\hline Percentage & - & - & 40 & 60 & - & \\
\hline \multicolumn{6}{|c|}{$\begin{array}{l}\text { Item 26. "My students adapt to different roles (friends, citizens, economic, power, family members) } \\
\text { in their lives". }\end{array}$} & 2 \\
\hline Frequency & 2 & 17 & - & 1 & - & \\
\hline Percentage & 10 & 85 & - & 5 & - & \\
\hline \multicolumn{6}{|c|}{ Item 27."My students are not comfortable with adapting to new situations." } & 1,95 \\
\hline Frequency & 2 & 17 & 1 & - & - & \\
\hline Percentage & 10 & 85 & 5 & - & - & \\
\hline \multicolumn{6}{|c|}{ Item 28. "My students are open to criticism. " } & 2 \\
\hline Frequency & - & 20 & - & - & - & \\
\hline Percentage & - & 100 & - & - & - & \\
\hline \multicolumn{6}{|c|}{ Item 29. "My students consider the different points of view to solve the problems". } & 3,1 \\
\hline Frequency & - & 1 & 16 & 3 & - & \\
\hline Percentage & - & 5 & 60 & 15 & - & \\
\hline \multicolumn{6}{|c|}{ Item 30. "My students know that learning is a lifelong process." } & 2 \\
\hline Frequency & 1 & 18 & 1 & - & - & \\
\hline Percentage & 5 & 90 & 5 & - & - & \\
\hline \multicolumn{6}{|c|}{ Item 31. "My students make use of past experiences to predict future events." } & 4,05 \\
\hline Frequency & - & - & - & 19 & 1 & \\
\hline Percentage & - & - & - & 95 & 5 & \\
\hline \multicolumn{6}{|c|}{ Item 32. "My students know when to talk and when to listen." } & 3,9 \\
\hline Frequency & - & - & 2 & 18 & - & \\
\hline Percentage & - & - & 10 & 90 & - & \\
\hline \multicolumn{6}{|c|}{ Item 33. "My students are respectful in their communication with others." } & 4,1 \\
\hline Frequency & - & - & - & 18 & 2 & \\
\hline Percentage & - & - & - & 90 & 10 & \\
\hline \multicolumn{6}{|c|}{ Item 34."My students respect to other cultures". } & 4,5 \\
\hline Frequency & - & - & 5 & - & 15 & \\
\hline \multirow[t]{2}{*}{ Percentage } & - & - & 25 & - & 75 & \\
\hline & & & & & & 3,19 \\
\hline
\end{tabular}

According to the mean values given in Table 7 regarding the opinions of the lecturers in terms of life and career skills used by ELL students, it could be claimed that the items with the highest level of agreement were "My students respect to other cultures" $(\overline{\mathrm{x}}=4,5)$, "My students are respectful in their communication with others" ( $\overline{\mathrm{x}}=4,1)$, "My students make use of past experiences to predict future events" ( $\overline{\mathrm{x}}=4,05)$, and "My students value individual contributions in group work" ( $\overline{\mathrm{x}}=4,05)$. On the other hand, the lowest level of agreement was observed for items "My students are not comfortable with adapting to new situations" ( $\overline{\mathrm{x}}=1,95)$, "My students know that learning is a lifelong process" $(\overline{\mathrm{x}}=2)$, "My students adapt to different roles (friends, citizens, economic, power, family members) in their lives" $(\overline{\mathrm{x}}=2)$ and "My students are open to criticism" $(\overline{\mathrm{x}}=2)$.

According to the research findings, participant ELL students studying at state universities responded "agree" to most of the sixteen items in the 21 st century skills competence perceptions "life and career skills" dimension $(\overline{\mathrm{x}}=4,03)$, while the lecturers were mostly "undecided" about the use of those skills by their students $(\overline{\mathrm{x}}=3,19)$. 


\section{Information, Media and Technology Skills}

Eight items in the questionnaire were related to information, media and technology skills. Table 8 presents some information given by the students about these 21 st century skills for learning.

Table 8. Information, media and technology skills

\begin{tabular}{|c|c|c|c|c|c|c|}
\hline & $\begin{array}{l}\text { Strongly } \\
\text { Disagree }\end{array}$ & Disagree & Undecided & Agree & $\begin{array}{l}\text { Strongly } \\
\text { Agree }\end{array}$ & $\begin{array}{c}\overline{\mathrm{x}} \\
(\text { Mean) }\end{array}$ \\
\hline \multicolumn{6}{|c|}{ Item 35. "I effectively use media and technology to communicate with others." } & 3,98 \\
\hline Frequency & 10 & 6 & 16 & 70 & 56 & \\
\hline Percentage & 6.3 & 3.8 & 10.1 & 44.3 & 35.4 & \\
\hline \multicolumn{6}{|c|}{ Item 36. "I know the purpose of the messages in media" } & 4,08 \\
\hline Frequency & 6 & 2 & 12 & 98 & 40 & \\
\hline Percentage & 3.8 & 1.3 & 7.5 & 62 & 25.3 & \\
\hline \multicolumn{6}{|c|}{ Item 37. "I know that media is effective in directing people's opinion". } & 4,36 \\
\hline Frequency & 4 & 4 & 10 & 52 & 88 & \\
\hline Percentage & 2.6 & 2.6 & 6.3 & 32.9 & 55.6 & \\
\hline \multicolumn{6}{|c|}{ Item 38. 'I use appropriate media tools to get information". } & 4,19 \\
\hline Frequency & 2 & 6 & 10 & 82 & 58 & \\
\hline Percentage & 1.3 & 3.8 & 6.3 & 51.9 & 36.7 & \\
\hline \multicolumn{6}{|c|}{ Item 39. "I use a diversity of media tools." } & 3,83 \\
\hline Frequency & 2 & 8 & 42 & 68 & 38 & \\
\hline Percentage & 1.3 & 5.1 & 26.5 & 43 & 24 & \\
\hline \multicolumn{6}{|c|}{ Item 40. "I use technological tools to acquire information. " } & 4,17 \\
\hline Frequency & 8 & - & 2 & 94 & 54 & \\
\hline Percentage & 5.1 & & 1.3 & 59.4 & 34.1 & \\
\hline \multicolumn{6}{|c|}{ Item 41. "'I use technological tools to analyse information. " } & 4,16 \\
\hline Frequency & 4 & 6 & 6 & 86 & 56 & \\
\hline Percentage & 2.6 & 3.8 & 3.8 & 54.4 & 35.4 & \\
\hline \multicolumn{6}{|c|}{ Item 42. "I use social network for sharing information". } & 3,79 \\
\hline Frequency & 10 & 10 & 32 & 66 & 42 & \\
\hline Percentage & 6.3 & 6.3 & 20.2 & 41.7 & 26.5 & \\
\hline
\end{tabular}

When the findings related to the views of ELL students on "Information, media and technology skills" dimension of the 21 st century skills in Table 8 was considered, the items with the highest level of agreement were "I know that media is effective in directing people's opinion" ( $\overline{\mathrm{x}}=4,36)$, "I use appropriate media tools to get information" $(\overline{\mathrm{x}}=4,19)$, "I use technological tools to acquire information" ( $\overline{\mathrm{x}}=4,17)$, and "I use technological tools to analyse information" $(\overline{\mathrm{x}}=4,16)$. However, the lowest level of agreement was observed for items "I use social network for sharing information" ( $\overline{\mathrm{x}}=$ $3,79)$, and "I use a diversity of media tools" ( $\overline{\mathrm{x}}=3,83)$.

The research findings showed that participant ELL students studying at state universities responded "agree" to most of the eight items in the 21 st century skills competence perceptions "information, media and technology skills" dimension $(\bar{x}=4,07)$. According to the results, the ELL students were aware of the information, media and technology skills more than the other skills.

This questionnaire was also adapted for lecturers to share their opinions about the use of 21 st century skills of ELL students. Table 9 presents some information about the opinions of the lecturers in terms of information, media and technology skills used by the ELL students. 
Table 9. Information, media and technology skills of ELL students

\begin{tabular}{|c|c|c|c|c|c|c|}
\hline & $\begin{array}{l}\text { Strongly } \\
\text { Disagree }\end{array}$ & Disagree & Undecided & Agree & $\begin{array}{l}\text { Strongly } \\
\text { Agree }\end{array}$ & $\overline{\mathrm{x}}($ Mean) \\
\hline \multicolumn{6}{|c|}{ Item 35."My students effectively use media and technology to communicate with others" } & 4,1 \\
\hline Frequency & - & - & - & 18 & 2 & \\
\hline Percentage & - & - & - & 90 & 10 & \\
\hline \multicolumn{6}{|c|}{ Item 36. "My students know the purpose of the messages in media" } & 3,25 \\
\hline Frequency & - & - & 15 & 5 & - & \\
\hline Percentage & - & - & 75 & 25 & - & \\
\hline \multicolumn{6}{|c|}{ Item 37. "My students know that media is effective in directing people's opinion." } & 2,3 \\
\hline Frequency & - & 18 & - & - & 2 & \\
\hline Percentage & - & 90 & - & - & 10 & \\
\hline \multicolumn{6}{|c|}{ Item 38. "My students use appropriate media tools to get information. " } & 2,25 \\
\hline Frequency & - & 15 & 5 & - & - & \\
\hline Percentage & - & 75 & 25 & - & - & \\
\hline \multicolumn{6}{|c|}{ Item 39."My students use a diversity of media tools." } & 3,75 \\
\hline Frequency & - & - & 5 & 15 & - & \\
\hline Percentage & - & - & 25 & 75 & - & \\
\hline \multicolumn{6}{|c|}{ Item 40."My students use technological tools to acquire information". } & 4 \\
\hline Frequency & - & - & - & 20 & - & \\
\hline Percentage & - & - & - & 100 & - & \\
\hline \multicolumn{6}{|c|}{ Item 41. "My students use technological tools to analyse information." } & 1,95 \\
\hline Frequency & 1 & 19 & - & - & - & \\
\hline Percentage & 5 & 95 & - & - & - & \\
\hline \multicolumn{6}{|c|}{ Item 42. "My students use social network for sharing information." } & 4 \\
\hline Frequency & - & - & 6 & 8 & 6 & \\
\hline Percentage & - & - & 30 & 40 & 30 & \\
\hline TOTAL & & & & & & 3,2 \\
\hline
\end{tabular}

Considering the mean values given in Table 9 regarding the opinions of the lecturers in terms of "Information, media and technology skills used by ELL students", it could be claimed that the items with the highest level of agreement were "My students effectively use media and technology to communicate with others" $(\overline{\mathrm{x}}=4,1)$, "My students use technological tools to acquire information" $(\overline{\mathrm{x}}=$ $4)$, and "My students use social network for sharing information $(\overline{\mathrm{x}}=4)$. On the other hand, the lowest level of agreement was observed for items "My students use technological tools to analyse information" $(\overline{\mathrm{x}}=1,95)$, and "My students use appropriate media tools to get information" $(\overline{\mathrm{x}}=2,25)$.

When the research findings were considered, participant ELL students responded "agree" to most of the eight items in the 21 st century skills competence perceptions "information, media and technology skills" dimension $(\bar{x}=4,07)$, while the lecturers were mostly "undecided" about the use of those skills by their students $(\overline{\mathrm{x}}=3,2)$.

All in all, when all the results were considered, it could be claimed that the participant ELL students were aware of most of the $21^{\text {st }}$ century skills while they reported that they used information, media and technology skills more than the other sub-skills. On the other hand, the lecturers were undecided about the use of all those skills. 


\section{Discussion}

The findings of the study comprising the analysis of the questionnaires for students and lecturers were examined to provide answers to each of the research questions below.

The research questions to be answered in this study are:

1) Are the students of ELL departments of two Turkish state universities aware of their own 21st century skills?

2) What are the levels of the 21 st century skills of the students of the ELL Departments of two Turkish state universities?

To be able to find answers to the research questions, a case study was carried out. The results of the questionnaires were analyzed and the conclusions will be discussed in this part. The conclusions were discussed over the findings of the study and the related literature in the light of each research question.

R.Q.1. Are the students of ELL departments of two Turkish state universities aware of their own 21 st century skills?

The first question of this study was designed to find out whether ELL students were aware of their own 21 st century skills. All three main parts of the questionnaire were discussed to find an answer to this research question. Firstly, the results of the study indicated that students used most of the learning \& innovation skills, life \& career skills and information, media \& technology skills effectively in their ELL courses. This finding indicated that the students of the ELL departments of two Turkish state universities were aware of their own 21st century skills.

R.Q.2. What are the levels of the 21st century skills of the students of the ELL Departments of two Turkish state universities?

The second research question investigated the levels of the 21st century skills of the students of the ELL Departments of two Turkish state universities. All three items of the questionnaire were discussed to find an answer to this research question.

With reference to the questionnaire for students and lecturers, the analysis of learning and innovation skills indicated that both the students and the lecturers agreed with the statements that the students developed original ideas for solving the problems they encountered, they tried different solutions to bring a problem to a conclusion, they used imagination to solve problems, they tried to understand the different dimensions of a topic, when solving the problem, they asked questions to determine the different points of view, they used reasoning methods to solve problems, in problem solution, they analyzed the relation between the part and the whole, they considered different points of view, they created synthesis by establishing relations between information and arguments, they reached conclusions by analyzing information, and they shared the knowledge they acquired with others in different ways. Additionally, both the students and the lecturers disagreed with the statement that they used time effectively.

On the other hand, while the students agreed with the statements that they used different thinking techniques (brainstorming, six thinking hat) to create original ideas in their lives, they evaluated new ideas by using analysis, they worked patiently to produce solutions to the problems, and they took steps to improve their skills, the lecturers disagreed with them. Moreover, while the students stated that they searched for the basis of a view by questioning the claim, and established out of the ordinary relations between part and the whole, the lecturers were undecided.

The analysis of life and career skills indicated that both the students and the lecturers agreed with the statements that they had the ability to work effectively in group work, worked in harmony with group members, took responsibility in group work, valued individual contributions in group work, were 
flexible in changing their ideas based on others' suggestions, made use of past experiences to predict future events, knew when to talk and when to listen, were respectful in their communication with others, and respected to other cultures. Additionally, both the students and the lecturers disagreed with the statement that they were not comfortable with adapting to new situations.

However, while the students agreed with the statements that they listened to other's opinion about a subject, had effective communication skills, adapted to different roles (friends, citizens, economic, power, family members) in their lives, were open to criticism and knew that learning was a lifelong process, the lecturers disagreed with them. Furthermore, while the students stated that they considered different points of view to solve the problems, the lecturers were undecided.

Finally, the analysis of information, media and technology skills indicated that both the students and the lecturers agreed with the statements that they effectively used media and technology to communicate with others, used a diversity of media tools, used technological tools to acquire information and used social network for sharing information. Nevertheless, while the students agreed with the statements that they knew that media was effective in directing people's opinion, used appropriate media tools to get information and used technological tools to analyse information, the lecturers disagreed with them. What's more, while the students stated that they knew the purpose of the messages in media, the lecturers were undecided.

\section{Conclusions}

In this part, the conclusions drawn from the case study are presented in the light of the research questions of the study. Then, the educational implications and suggestions for further studies are presented.

The following conclusions are based on the results of the data gathered from the 158 student and 20 lecturer respondents of the questionnaire. The conclusions are expanded in the light of all the findings regarding the responses of the participants:

Firstly, whether the ELL students were aware of their own 21 st century skills were analysed and the results showed that students the students used most of the learning \& innovation skills, life \& career skills and information, media \& technology skills effectively in their ELL courses. This finding indicates that the students of the ELL departments of two Turkish state universities are aware of their own 21st century skills. However, they stated that they used information, media \& technology skills more than the other skills.

Another conclusion related to the results of the study indicated that although most of the students stated that they were using most of the 21 century skills, the lecturers did not approve of them. They stated that the students did not use different thinking techniques to create original ideas in their lives, evaluate new ideas by using analysis, work patiently to produce solutions to the problems, and they did not take steps to improve their skills. Additionally, they disagreed with the statements that the students listened to other's opinion about a subject, had effective communication skills, adapted to different roles in their lives, were open to criticism, knew that learning was a lifelong process, knew that media was effective in directing people's opinion, used appropriate media tools to get information and used technological tools to analyse information.

\subsection{Implications for Educational Practice}

Based on the findings presented, this study holds the following overall implications for educational practice: 
- $21^{\text {st }}$ century literature works are expected to be used more than classical ones to be able to give the learners a chance to reflect their interests to the current themes and issues.

- In a globalised world, it is better to use World English Literature rather than the British and American ones to teach learners about others.

- Like in real life, in literature classes, students may volunteer to play characters of a story to resolve conflicts and develop their $21^{\text {st }}$ century skills.

- Classroom environments are expected to be suitable for debate and inquiry for developing critical thinking skills.

- To engage students in interactive learning situation, collaborative works as literature circles, conversations surrounding texts, literature group discussions, etc. can be encouraged.

- students are to engage in investigating real world issues, solving problems and taking responsibilities. As a result, they are to be assigned to challenging tasks to solve problems.

- Lecturers are expected to find ways to develop $21^{\text {st }}$ century skills of ELL students as creativity, critical thinking, communication and collaboration (4Cs) (Ahmed, 2018).

\subsection{Suggestions for Further Studies}

In this study, 158 3rd and 4th year students studying at two Turkish state universities have participated. It is recommended that further studies be conducted to investigate the 21st century skills of the 1st and 2nd year students studying at the same departments of these state universities. Some other studies can be conducted to find out the 21 st century skills of other state universities in different regions of Turkey. Some comparative studies can be done to compare the 21 st century skills of the students studying at different ELL departments in Turkey. As a more longitudinal study, the suggested applications given in this study about reforming the curriculum and the teaching methods used in literature courses with a 21 st century perspective can be implemented and the results can be evaluated.

\section{Ethics Committee Approval}

The authors confirm that ethical approval was obtained from Ankara Hacı Bayram Veli University (Approval Date: 02.12.2020).

\section{References}

Ahmed, M. (2018). The 21st century skills and the role of literature at the English department. Journal of Language, Linguistics and Literature, 4(3), 34-38.

Anagün Ş.S., Atalay N., Kılıç Z., \& Yaşar S. (2016). Öğretmen adaylarına yönelik 21. yüzyıl becerileri yeterlilik algıları ölçeğinin geliştirilmesi ve güvenirlik çalışması. PAU Eğitim Fakültesi Dergisi, 40, $160-175$.

Bedir, H. (2019). Pre-service ELT teachers' beliefs and perceptions on 21st century learning and innovation skills (4Cs). Journal of Language and Linguistic Studies, 15(1), 231-246.

Kan, A. Ü. \& Murat, A. (2018). Investigation of prospective science teachers' 21st century skill competence perceptions and attitudes toward STEM. International Online Journal of Educational Sciences, 10(4), 251-272.

Perry, M. S. (2019). Literature for the twenty-first century: Developing multimodality and entrepreneurial skills through literature-based assessments. Kritika Kultura, 33/34. 428-454. 
Sümen, Ö. Ö. \& Çalışıc1, H. (2017). Examining the 21st century skills of secondary school students: A mixed method study. Journal of Education and Social Policy, 4(4), 92-100.

Tican, C. \& Sabahattin, D. (2018). Pre-service teachers' opinions about the use of 21 st century learner and 21st century teacher skills. European Journal of Educational Research, 8(1), 181-197.

\section{İngiliz dili ve edebiyatı öğrencilerinin 21. yüzyıl becerilerinin farkındalığ1}

\section{Öz}

Bu çalışmanın amacı, iki Türk devlet üniversitesinin İngiliz Dili ve Edebiyatı Bölümünde öğrenim gören üçüncü ve dördüncü sınıf öğrencilerinin 21. yüzyıl becerilerini ne derece kullandıklarını incelemektir. Ayrıca öğrencilerin 21. yy. beceri düzeylerinin keşfedilmesi amaçlanmaktadır. Bu nedenle, İngiliz Dili Edebiyatı bölümünde okuyan 158 öğrenci ve 20 öğretim üyesi ile bir vaka çalışması tasarlanmış ve yürütülmüştür. Araştırma 2019-2020 eğitim öğretim yılında yapılmıştır. İlgili literatür gözden geçirilmiş ve verilerin toplanmasında kullanılacak iki araştırma aracı buna göre seçilmiştir. İngiliz Dili ve Edebiyatı öğrencilerinin 21. yüzyıl becerilerini araştırmak amacıyla öğrenciler ve öğretim üyeleri için iki ayrı anket kullanılmıştır. Verilerin nicel analizi, iki Türk devlet üniversitesinin İngiliz Dili ve Edebiyatı bölümlerinde okuyan öğrencilerin kendi 21. yüzyıl becerilerinin farkında olduklarını ortaya koymuştur. Araştırmanın sonuçlarına ilişkin bir başka sonuç ise öğrencilerin çoğu 21. yüzyıl becerilerinin çoğunu kullandıklarını belirtmesine rağmen öğretim üyelerinin bunları onaylamadığını göstermektedir. Öğrencilerin hayatlarında özgün fikirler oluşturmak için farklı düşünme tekniklerini kullanmadıklarını, analizleri kullanarak yeni fikirleri değerlendirmediklerini, sorunlara çözüm üretmek için sabırla çalıșmadıklarını ve becerilerini geliştirmek için adımlar atmadıklarını belirtmişlerdir. Ayrıca öğrencilerin bir konu hakkında başkalarının görüşlerini dinlemedikleri, etkili iletișim becerilerine sahip olmadıkları, yaşamlarında farklı rollere adapte olmadıkları, eleştiriye açık olmadıkları, öğrenmenin yaşam boyu sürecek bir süreç olduğunu bilmedikleri, medyanın etkili olduğunu bilmedikleri öğretim üyeleri tarafından belirtilmiştir.

Anahtar sözcükler: 21.yüzy1l becerileri; İngiliz dili ve edebiyatı öğrencileri; öğrenme ve yenilik becerileri; yaşam ve kariyer becerileri; bilgi, medya ve teknoloji becerileri

\section{AUTHOR BIODATA}

Prof. Dr. Gülsev Pakkan currently works at the Department of ELL at Selçuk University as a full professor. She is a graduate of the English Linguistics Department of Hacettepe University. She completed her MA and PhD at the same department. She worked at Gazi University for 9 years and 13 years for Hacettepe University. She also worked at Ufuk University as the head of the ELT Department. She also worked at the Faculty of Education as the head of the ELT Department at Başkent University. She also worked at the Department of Translation and Interpreting as the head. Her interest areas are materials development, teacher education, the teaching of language skills.

Dr Aydan Irgatoğlu works as an assistant professor at School of Foreign Languages of Ankara Hacı Bayram Veli University. She is also working there as vice president. She is a graduate of the English Language Teaching Department of Hacettepe University. She completed her MA and PhD at the same department of Gazi University. She worked at Başkent University for 10 years and she also worked as the head of the department of Translation and Interpreting at Başkent University. Her interest areas are L2 teacher education and language learning strategies. 